\title{
Safety Measure and First Aid Program among Workers in Delta Fertilizer and Chemical Company regarding Occupational Health Hazards
}

\author{
Mai Nour- Eldien Mohammed ${ }^{1}$, Howyida Sadek Abd El-Hameed ${ }^{2}$ and Doaa Mohamed \\ Sobhy $^{3}$
}

(1)Nursing Specialist, Specialized Medical Hospital in Mansoura, Egypt, (2) Professor of Community Health Nursing, Faculty of Nursing, Benha University, Egypt and (3) Assistant Professor of Community Health Nursing, Faculty of Nursing, Benha University, Egypt

\begin{abstract}
:
Background: Safety measures are strategies aim at eliminating or reducing the occurrence of hazardous agents and factors in the work environment to acceptable levels, preferably at their source of generation. Aim of study: Was to evaluate safety measures and first aid program among workers in Delta Fertilizer and Chemical Company regarding occupational health hazards. Research design: A quasi -experimental design was utilized in this study. Setting: The study was conducted at Delta Fertilizers and Chemicals Company at Talkha City. Sample: A systematic random sample was used, it consisted of 349 workers. Tools of data collection: Two tools were used in this study. I: Structured questionnaire sheet included four parts: Socio demographic characteristic of the workers, work data, past history of occupational injury or problem and workers' knowledge about occupational health hazards and II: Observational checklist: Was consisted of three parts: Observing the workers practice about using personal protective equipment, first aid procedures and the environment condition of fertilizer and chemicals company. Results: There was improvement in workers total knowledge score (Mean \pm SD $8.0 \pm 3.7$ pre program to $34.8 \pm 11.5$ post program to $29.0 \pm 10.8$ after 3 mounths), total practice highly statically significant difference (Mean \pm SD $17.2 \pm 6.9$ pre program to $23.1 \pm 3.8$ post program to $20.6 \pm 3.7$ after 3mounths. Conclusion: Studied workers' knowledge and practice were improved significantly post program and 3 months after program. Recommendation: Increase awareness about training courses for workers regarding safety measure and first aid of occupational health hazards.
\end{abstract}

Keywords: Safety measures, First aid, Occupational health hazards, Fertilizer and chemical

\section{Introduction:}

Fertilizes industry is one of the most important and large industries in Egypt which include several chemical processes beside physical operations take place. Several Egyptian companies are producing two basic types of fertilizers, which include nitrogenous and phosphate fertilizers (Egyptian Environmental Affairs Agency, 2019).

Workers represent half of the world's population. Maintaining a safe working environment is reflected on a healthy worker.
Some reasons for not implementing the safety policy by most developing countries are lack of effective enforcement system, lack of information and accurate records of occupational diseases, accidents, and lack of basic professional training in occupational health and safety (World Health Organization (WHO), 2017).

Occupational health means provision of comprehensive health care to workers through a mix of primitive, preventive, curative and rehabilitative interventions so as 


\section{Safety Measure and First Aid Program among Workers in Delta Fertilizer and Chemical Company regarding Occupational Health Hazards}

to raise their quality of life. It is also defined as the effect of working environment and work on the health of the workers and turns the effect of workers health status on the productivity (Wilcock, 2020).

Safety measures are strategies aim at eliminating or reducing the occurrence of hazardous agents and factors in the work environment to an acceptable levels, preferably at their source of generation, secondly during their part of transmission and lastly by protecting the worker. Modifications include, correct operation and maintenance of process and equipment, enclosure and closed systems, good work practices, as well as personal protective equipment, information, training and education of workers and employers regarding hazards and their prevention (including an emergency response) should also be part of such strategies order to ensure the continued efficiency of preventive measures (WHO, 2019).

Strategies aim at eliminating or reducing the occurrence of hazardous agents and factors in the work environment to acceptable levels, preferably at their source of generation, secondly during their part of transmission and lastly by protecting the worker. Modifications include, correct operation and maintenance of process and equipment, enclosure and closed systems, good work practices, as well as personal protective equipment, information, training and education of workers and employers regarding hazards and their prevention (including an emergency response) should also be part of such strategies order to ensure the continued efficiency of preventive measures (WHO, 2019).
First aid is the first and immediate assistance given to any person suffering from either a minor or serious illness or injury, with care provided to preserve life, prevent the condition from worsening, or to promote recovery. It includes initial intervention in a serious condition prior to professional medical help being available, such as performing cardiopulmonary resuscitation while waiting for an ambulance, as well as the complete treatment of minor conditions, such as applying a plaster to a cut. First aid is generally performed by someone with basic medical training (Peterson, 2018).

The occupational health nurse has an important role in preventing occupational hazards, industries hazards, through determining the worker's health problems, identify the industrial health hazards and dangerous conditions to health, plan and promote worker's health by providing appropriate treatment. The industrial health nurse also participates in implementing a safety plan to prevent or minimize accidents and injuries that occur during daily activities. Assesses workers needs, develops appropriate educational program by using formal and informal presentation, has a role workers training to use preventive measures during working, encourages workers to use health services, evaluates effectiveness of workers response to nursing actions and control of environmental factors that cause a disease (Levy, 2019).

\section{Significance of the study:}

The International Labor Organization reported that despite the fact that occupational diseases kill six times as many people, accidents attract greater attention. Of the estimated 2.34 million annual workrelated deaths, the vast majority - 
approximately 2.02 million - are due to workrelated diseases. This represents a daily average of 5,500 deaths. The International Labor Organization (ILO) also estimates that 160 million cases of non-fatal work-related diseases occur annually (ILO, 2017).

Occupational hazards are the major source of morbidity and mortality among the factory workers owing to exposure to many hazardous situations in their daily practices. Occupational hazard is a risk to a person in working environment besides the consequences like fatal accidents, minor to severe injuries, and allergic and systemic effects which occur immediately, whereas there are those that appear at a later period, or an occupational hazard is something unpleasant that one may suffer or experience as a result of doing in job (World Health Organization, 2018).

The primary goals of occupational health studies are to reduce hazard exposure and to prevent disease and injury. Provision of services to meet these goals includes assessment and monitoring of the workplace and the general environment for health and safety measures (Wang et al., 2018)

\section{Aim of the study:}

This study aimed to evaluate safety measure and first aid program among workers in Delta Fertilizer and Chemical Company regarding occupational health hazards.

\section{Research Hypothesis}

Knowledge and practice of workers in Delta Fertilizer and Chemical Company would improve after implementation of safety measures and first aid program.

\section{Subjects and method:}

\section{Research design:}

Quasi experimental design was used in carrying out this study.

\section{Setting:}

The study was conducted at Delta Fertilizers and Chemicals Company at Talkha City

\section{Sampling:}

A systematic random sample will be used in this study. The total number of fertilizer factory workers was 2732 they were working in different departments. The sample size was349 workers who agreed to participate in the study according to the following equation: (Yamane, 1967)

$$
\begin{aligned}
& \mathrm{n}=\frac{\mathrm{N}}{1+\mathrm{N}(\mathrm{e})^{2}} \\
& \mathrm{n}=\text { the sample size } \\
& \mathrm{N}=\text { total population } \\
& \mathrm{e}=0.05
\end{aligned}
$$

\section{Inclusion criteria:}

Workers age more than 18 years old.

Tools for Data Collection: Two tools were used for data collection.

I: An Interviewing questionnaire sheet included four parts:

Part (1) : Socio demographic characteristic of the workers which covered age, educational level, marital status, number of family members, training courses about health and safety, number of training courses and content of training courses.

Part (2): Work data and training courses of the workers which included work hours, experience years take training courses about 
occupational health and safety and number of attended courses.

Part (3): Past history of occupational injury or problem which included two questions about suffering from any disease and past injuries during work

Part (4): Workers knowledge about occupational health hazards which consist of 27 items.

\section{Scoring system:}

Each item was assigned a score of (2) given when the answer was complete correct answer, a score (1) was given when the answer was incomplete correct answer and a score (0) was given when the answer was don't known. The total score of each section was calculated by summation of the scores of its items. The total score for the knowledge of a participant was calculated by the addition of the total score of all sections. Workers total knowledge score was classified as the following:

Total scores of knowledge $=54$

- Good when total score was $75 \%$ to $100 \%$ ( $\geq 41$ score),

- Average when the total score was $50 \%$ to less than $75 \%(27-41)$.

- Poor when the total score was less than $50 \%(<27)$.

II-Observational checklist: Assess workers practice and working environment.

A- Workers practice included two parts:

Part (1): Included workers practice about first aid procedures included 4 items (first aid for fractures (10 items), wound and bleeding (13 items), burn (10 items), electrical shock (6 items)

\section{Scoring system:}

Done $=1 \quad$ Not done $=0$

Part (2): Involved usage of personal protective equipment which included 9items.

\section{Scoring system:}

Available and used $=1$

Available and not used $=0$

Not available $=0$

Satisfactory when the total score was $\geq 60 \%$ ( $\geq$ 29score)

Unsatisfactory when the total score was less than $60 \%(<29$ score $)$.

Part (3): Involved environmental and sanitation condition of the studied fertilizer factory which covered 9 items area of work( 3 statments), floor (1statment), emergency exit (2statements), health clinic (3statments), fire protection (3statments), material handling (1statment), storage (3statments) ,machines (2statments) and employee facilities (1statment).

\section{Scoring system:}

Available $=1 \quad$ Not available $=0$

The total score of the environmental and sanitation condition considered safe and sanitary if score $\geq 80 \%(\geq 7)$ and considered un safe and un sanitary if it $<80 \%(<7)$

\section{Reliability and content validity of the tools:}

The tools were reviewed for comprehensiveness, appropriateness, and legibility by an expert panel consisting of five experts of faculties nursing staff from the community specialties. The panel ascertained the face and content validity of the tools. The reliability was done by Cronbach's Alpha coefficient test which revealed that each of the two tools consisted of relatively homogenous items as indicated by the 
moderate to high reliability of each tool .The internal consistency of knowledge was (.85) , 0.96 for practice.

\section{Ethical consideration:}

Approvals to conduct the study was obtained from the authorized personnel concerned the title, objectives, tools; the study technique was illustrated to gain their cooperation which is needed to allow the researcher to meet the studied sample at chosen setting. The agreement for participation were taken orally before conducting the interview and given a brief orientation to the purpose of the study. The working was also reassured that all information gathered would be confidentially and used only for the purpose of the study. No names required on the forms to ensure anonymity and confidentiality. They were also informed about their right to withdraw at any time from the study without giving any reasons.

\section{Pilot study:}

Before starting data collection, a pilot study was conducted using the developed questionnaire on 35 participants (10\% of the study sample). The pilot study was carried out to test the applicability and clarity of the constructed questionnaire and detect any obstacles or problems that might arise during the actual collection of data. Also, to estimate the time needed to fill the sheet with the total sample of the study the necessary modification and clarification was done. The pilot sample included in the study.

\section{Field work:}

\section{Data collection procedure:}

- Data collection for this study was carried out at the first of September 2019 and completed by the end of Fairbury 2020.
- The researcher constructed the tool of the study after reviewing the literature that cover the various aspects of the problem by using books, periodical articles and network.

- The data was collected by using selfadministered questionnaire once permission was granted; the researcher was initiated collection of data through arranging meetings at the inter company of the selected settings.

- The questionnaire was filled while the worker inter company

- Each worker who approved to participate in the study and fulfilled the selection criteria was asked to fill the questionnaire for a period of 20 minutes to collect socio-demographic data, and answering other tool questions.

- The obtained information (pre-test) served as baseline assessment for the worker.

- After collection of the pretest data, educational program was given to the workers based on their answers and weak points of their knowledge and practice.

- Post-test was done after the educational program to evaluate the effectiveness of the educational program on improving knowledge and practice program of the workers regarding first aid and safety measure.

- Workers who were included in the program were divided into groups; each group consisted of 15-20 Workers.

- Each group attended 6 sessions and the duration of each session was 60 minutes.

- The researcher implemented the program through 4 phases as the following:

\section{Assessment phase:}

Extensive review of the recent and past available national and international references related to the research was made 
using magazines, text books, periodicals, journal and internet search was made. This was important for the investigator to be oriented about aspects of the research problem in addition to assist in the development of tools of data collection.

\section{Planning phase:}

An objective of the program was to improve workers knowledge and practice to prevent occupational health hazards of chemical fertilizers.

\section{Implementation phase:}

- The program was implemented in a period of six month from the beginning of September 2019 to the end of February 2020.The researcher introduces the program in 6 sessions. During the session group of 15-20 workers was attended and total hours of the sessions were ( 3 hours theoretical and 3 hours practical).

- The interview questionnaire conducted by the researcher for data collection in the selected setting, after getting the necessary official permission; the researcher introduced herself and asked the questionnaire used simple Arabic language.

- The researcher visited workers 3days /week from 11.00 a.m.to 12.00 mid-day, sometime from 9.00 am to10 .00 am to collect the data.

- The expected duration of each session was 60 minutes, use 6 session,3theoretical and 3practice,used group discussion also booklet utilized, with clearance of general and specific objectives as follow:

- First session: At the beginning of the first session, an orientation to the program, Explained types of fertilizer, fertilizes penetration method, definition occupational health hazards taking into consideration the use of simple language according to the educational level. Discussion, motivation and reinforcement during session were used to enhance learning. Each session started by summary about the previous session and objectives of new topics.

- Second session: Types of occupational health hazards, factors that increase risk of hazard, safety measure and ways to prevent occupational health hazards.

- Third session: Definition of first aid, purposes of first aid, important injuries that need first aid, 9qualities of first aider while performing first aid components of first aid kit, prevention of occupational health hazards

- Fourth session: Apply first aid of wound and bleeding.

- Fifth session: Apply first aid of burn and first aid of electric shock.

- Six sessions: Apply first aid of fracture and proper use of PPE.

\section{Evaluation phase:}

After the implantation of the program, the post test was done to workers to assess knowledge and practice by the same format of the pre -test to evaluate the effectiveness of the implemented program. This was done immediately after the of program implementation and after 3 months.

\section{Statistical analysis:}

Data was coded and transformed into specially designed form to be suitable for computer entry process. Data was entered and analyzed by using SPSS (Statistical Package for Social Science) statistical package version 22. Graphics were done using Excel program. Quantitative data were presented by mean (X) and standard deviation (SD). It was analyzed 
using student t- test for comparison between two mean, however, if the data was not normally distributed, non-parametric tests were used. Qualitative data were presented in the form of frequency distribution tables, number and percentage. It was analyzed by chi-square $(\chi 2)$ test. However, if an expected value of any cell in the table was less than 5 , Fisher Exact test was used. Level of significance was set as $\mathrm{P}$ value $<0.05$ for all significant tests.

$$
\begin{array}{ll}
\mathrm{P}>0.05 & \text { Not significant } \\
\mathrm{P}<0.05 * & \text { Significant } \\
\mathrm{P}<0.001 * * & \text { Highly significant }
\end{array}
$$

\section{Results}

Table (1):Reveals socio demographic characteristics of the studied workers, it shows that, $60.2 \%$ of the studied workers were aged $30-<40$ years with mean \pm SD $35.5 \pm 9.6$ and $64.8 \%$ of the studied workers had secondary education, $80.2 \%$ of them were married. Also, $90.3 \%$ of the studied workers had 3-5 members in family.

Table (2): Reveals that (100\%) of the studied workers had training courses about types of fertilizers and fertilizer health hazards. And $49.3 \%$ of the studied workers attended training about the right way to manufacture it.

Table (3):Clears that there were highly statistically significant difference among all items (the occupational hazards of chemical fertilizers and diseases results from working, first aid in the event of exposure to injury while working, ways to prevent occupational hazards resulting from work) of studied workers total knowledge domains among pre- program , post- program and 3 months after program $<0.001$

Figure (1): Illustrates that 58.2 of studied workers had poor of total level of knowledge pre- program, which decrease to 7.4 in post program, and became 21.63 months after intervention.

Figure (2): Reveals that $73.6 \%$ of studied workers had unsatisfactory total level of practices pre- program, which decreased to $55.3 \%$ in post program, and became $69.9 \% 3$ months after program.

Table (4): Reveals that there was highly statistically significant difference among practice domains of studied workers during pre-program, post- program and 3 months after program $p<0.000$.

Table (5): There was statistically significant correlation between the studied workers total knowledge and total practices among preprogram, post- program and 3 months after program. 
Safety Measure and First Aid Program among Workers in Delta Fertilizer and Chemical Company regarding Occupational Health Hazards

Table 1: Distribution of workers regarding their socio demographic data $(n=349)$

\begin{tabular}{|l|l|l|}
\hline Personal data & N & $\%$ \\
\hline Age & 35 & 10.0 \\
\hline$<20$ & 34 & 9.7 \\
\hline $20-<30$ & 210 & 60.3 \\
\hline $30-<40$ & 35 & 10.0 \\
\hline $40-<50$ & 35 & 10.0 \\
\hline$>50$ & $35.5 \pm 9.6$ & \\
\hline Mean \pm SD & \multicolumn{2}{|l|}{} \\
\hline Educational level & 70 & 20.0 \\
\hline Primary & 226 & 64.8 \\
\hline Secondary & 53 & 15.2 \\
\hline University & 35 & 10.0 \\
\hline Marital Status & 280 & 80.3 \\
\hline Single & 34 & 9.7 \\
\hline Married & \multicolumn{1}{|l|}{34} \\
\hline Widow & 315 & 9.7 \\
\hline Number of family member & 90.3 \\
\hline 3 member & \multicolumn{1}{|l|}{} \\
\hline 4-5 member &
\end{tabular}

Table 2: Distribution of the studied workers according to work data and training courses $(\mathbf{n}=349)$.

\begin{tabular}{|l|l|l|}
\hline Work data & $\mathbf{N}=\mathbf{3 4 9}$ & $\mathbf{\%}$ \\
\hline Work hours & 349 & 100.0 \\
\hline $\mathbf{6}-\mathbf{8}$ hours & 105 & 30.1 \\
\hline Experience years & 209 & 59.9 \\
\hline$<\mathbf{5}$ & 35 & 10.0 \\
\hline $\mathbf{5}-\mathbf{1 0}$ & $7.6 \pm 3.6$ & \\
\hline$>\mathbf{1 0}$ & 140 & 40.2 \\
\hline Mean $\mathbf{l}$ SD & \multicolumn{1}{|l|}{209} & 59.8 \\
\hline Training courses about occupation health & \multicolumn{1}{|l|}{} \\
\hline Yes & 71 & 50.7 \\
\hline No & 69 & 49.3 \\
\hline Number of attended course &
\end{tabular}


Table 3: Comparison of workers total level of knowledge at throughout the program phases $(\mathbf{n}=349)$.

\begin{tabular}{|c|c|c|c|c|c|c|c|c|}
\hline \multirow[t]{2}{*}{ Total knowledge } & \multicolumn{2}{|c|}{ Pre $(n=349)$} & \multicolumn{2}{|c|}{ Post $(n=349)$} & \multicolumn{2}{|c|}{$\begin{array}{l}\text { After3 M } \\
(n=349)\end{array}$} & \multicolumn{2}{|c|}{ Chi square test } \\
\hline & $\overline{\mathrm{N}}$ & $\%$ & $\mathrm{~N}$ & $\%$ & $\mathrm{~N}$ & $\%$ & $\overline{X^{2}}$ & $\bar{P}$ \\
\hline \multicolumn{9}{|c|}{$\begin{array}{l}\text { The occupational hazards of chemical } \\
\text { fertilizers }\end{array}$} \\
\hline Poor & 201 & 57.6 & 34 & 9.7 & 80 & 22.9 & & \\
\hline Fair & 133 & 38.3 & 57 & 16.3 & 102 & 29.2 & & \\
\hline Good & 15 & 4.3 & 258 & 73.9 & 167 & 47.9 & 377.27 & $<0.001$ \\
\hline Mean \pm SD & \multicolumn{2}{|c|}{$3.3 \pm 1.16$} & \multicolumn{2}{|c|}{$16.3 \pm 3.7$} & \multicolumn{2}{|c|}{$10.5 \pm 3.8$} & 344.69 & $<0.001$ \\
\hline \multicolumn{9}{|c|}{ Diseases results from working } \\
\hline Poor & 216 & 61.9 & 32 & 9.2 & 81 & 23.2 & & \\
\hline Fair & 100 & 28.7 & 45 & 12.9 & 112 & 32.1 & & \\
\hline Good & 33 & 9.5 & 272 & 77.9 & 156 & 44.7 & 381.31 & $<0.001$ \\
\hline Mean \pm SD & \multicolumn{2}{|c|}{$1.2 \pm 0.6$} & \multicolumn{2}{|c|}{$7.8 \pm 3.2$} & \multicolumn{2}{|c|}{$4.5 \pm 2.2$} & 738.46 & $<0.001$ \\
\hline \multicolumn{9}{|c|}{ First aid to injury while working } \\
\hline Poor & 196 & 56.2 & 23 & 6.6 & 71 & 20.3 & & \\
\hline Fair & 106 & 30.4 & 46 & 13.2 & 116 & 33.2 & & \\
\hline Good & 47 & 13.5 & 280 & 80.2 & 162 & 46.4 & 363.65 & $<0.001$ \\
\hline Mean \pm SD & \multicolumn{2}{|c|}{$1.9 \pm 0.9$} & \multicolumn{2}{|c|}{$11.2 \pm 4.8$} & \multicolumn{2}{|c|}{$6.5 \pm 2.9$} & 701.78 & $<0.001$ \\
\hline \multicolumn{9}{|c|}{ Ways to prevent occupational hazards } \\
\hline Poor & 200 & 57.4 & 15 & 4.3 & 70 & 20.1 & & \\
\hline Fair & 114 & 32.7 & 35 & 10.0 & 121 & 34.7 & & \\
\hline Good & 35 & 10.0 & 299 & 85.7 & 158 & 45.3 & 453.50 & $<0.001$ \\
\hline
\end{tabular}

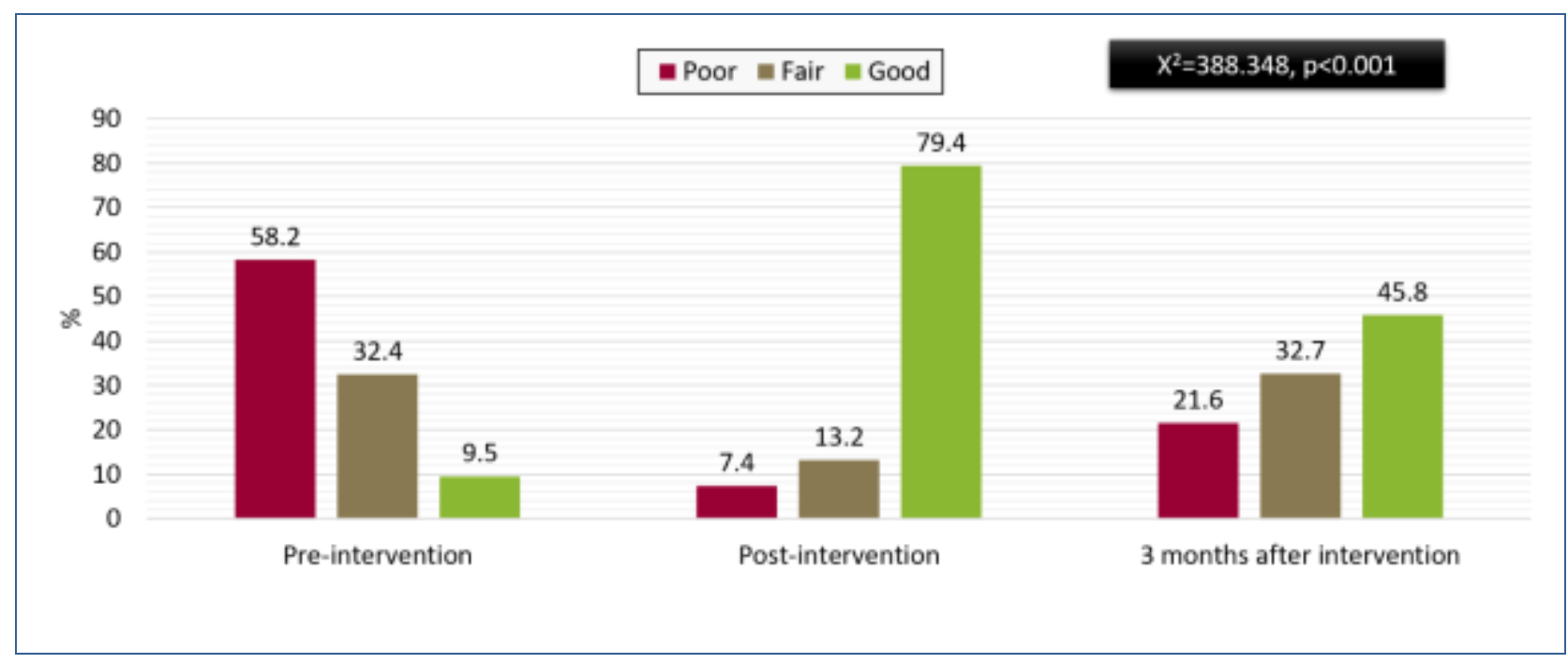

Figure 1. Comparison of workers total knowledge among pre-intervention, post-intervention and 3 months after intervention 


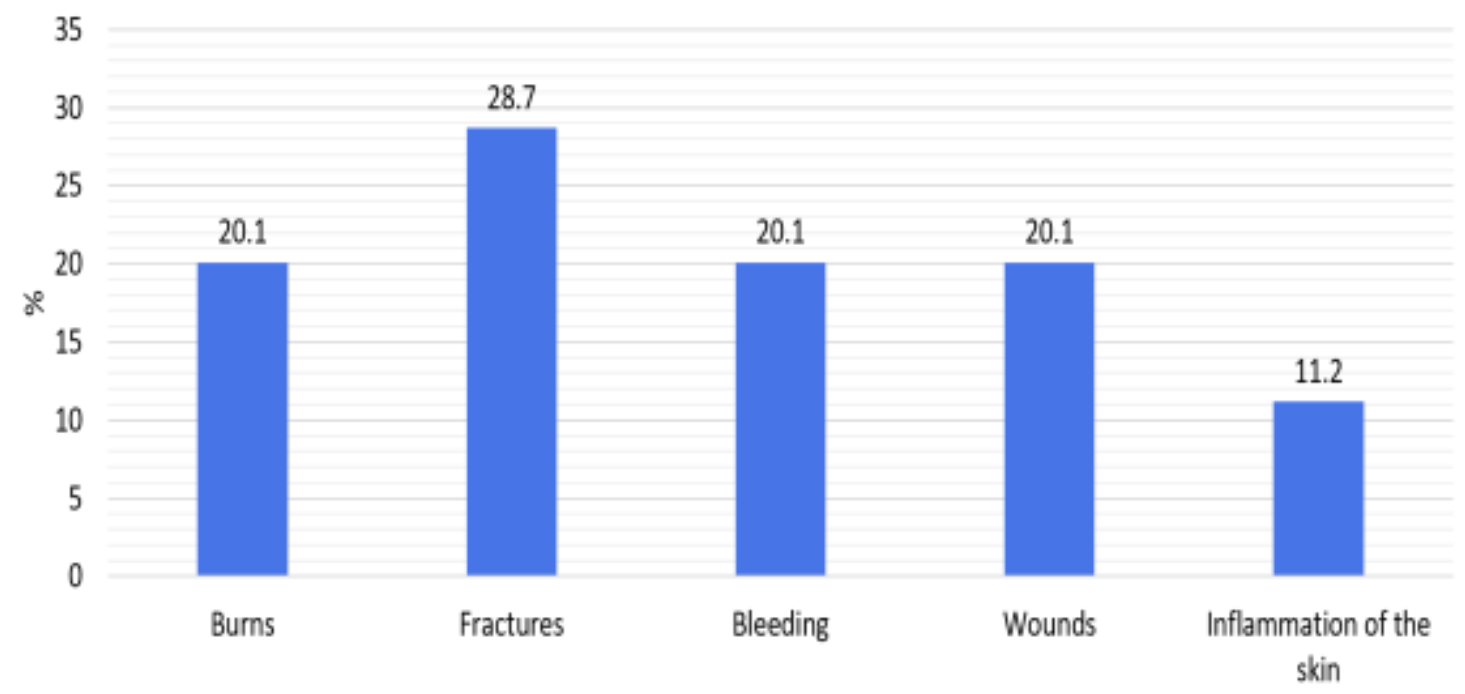

Figure (2): Percentage distribution of workers regarding history of previous injuries

Table 4: Comparison of workers total level of practices domains regarding physical injuries throughout the program phases $\quad(n=349)$

\begin{tabular}{|c|c|c|c|c|c|c|c|c|}
\hline \multirow[t]{2}{*}{ Workers practices } & \multicolumn{2}{|c|}{ Pre $(n=349)$} & \multicolumn{2}{|c|}{ Post $(n=349)$} & \multicolumn{2}{|c|}{$\begin{array}{l}\text { After3 } \\
\text { months } \\
(n=349)\end{array}$} & \multicolumn{2}{|c|}{ Chi square test } \\
\hline & No & $\%$ & No & $\%$ & No & $\%$ & $\mathrm{X}^{2}$ & $\mathrm{P}$ \\
\hline \multicolumn{9}{|l|}{ Fracture } \\
\hline Unsatisfactory & 206 & 59.0 & 100 & 28.7 & 142 & 40.7 & & \\
\hline Satisfactory & 143 & 41.0 & 249 & 71.3 & 207 & 59.3 & 66.70 & $<0.001$ \\
\hline \multicolumn{9}{|l|}{ Bleeding and wound } \\
\hline Unsatisfactory & 220 & 63.0 & 156 & 44.7 & 212 & 60.7 & & \\
\hline Satisfactory & 129 & 37.0 & 193 & 55.3 & 137 & 39.3 & 28.30 & $<0.001$ \\
\hline \multicolumn{9}{|l|}{ Burn } \\
\hline Unsatisfactory & 257 & 73.6 & 152 & 43.6 & 209 & 59.9 & & \\
\hline satisfactory & 92 & 26.4 & 197 & 56.4 & 140 & 40.1 & 65.46 & $<0.001$ \\
\hline \multicolumn{9}{|l|}{ Electric shock } \\
\hline Unsatisfactory & 258 & 73.9 & 196 & 56.2 & 249 & 71.3 & & \\
\hline Satisfactory & 91 & 26.1 & 153 & 43.8 & 100 & 28.7 & 29.15 & $<0.001$ \\
\hline
\end{tabular}




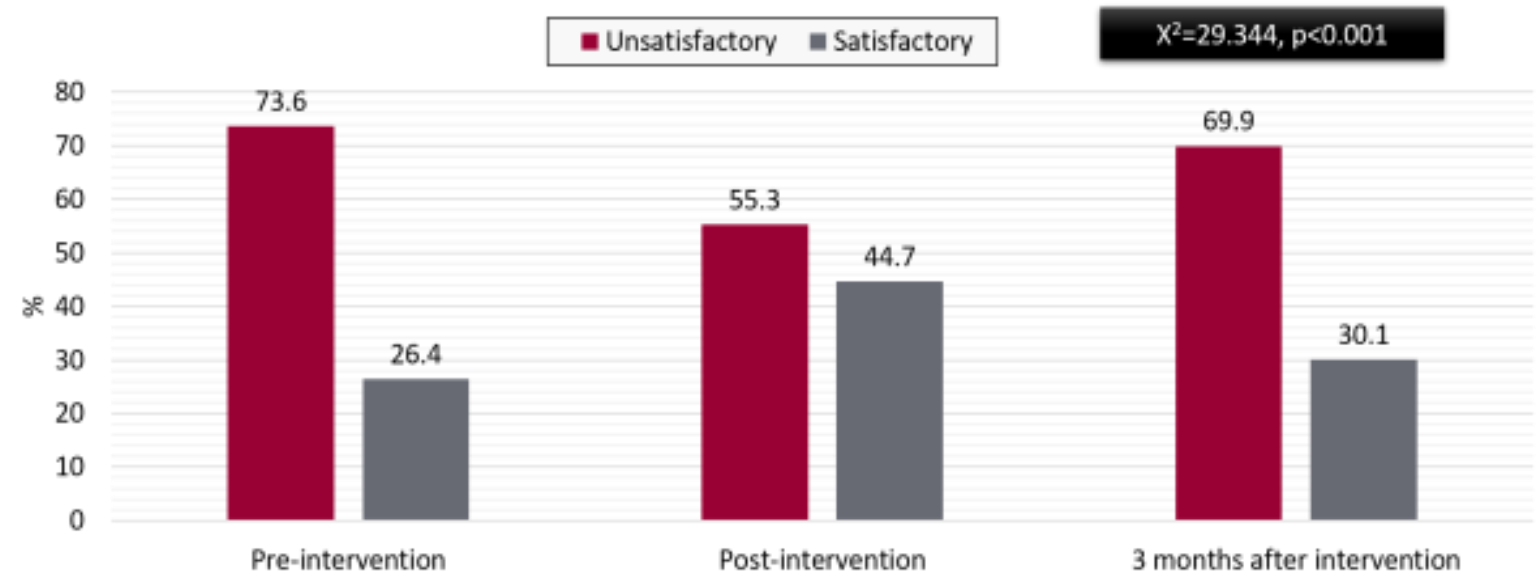

Figure (3): Comparison of workers total level of practice among pre, post and 3 months after program.

Table 5: Correlation between the worker's total knowledge level and total practice level at pre, post and 3 months after program $(n=349)$.

\begin{tabular}{|c|c|c|c|c|c|c|c|c|c|c|c|c|c|c|c|c|c|c|c|c|c|}
\hline & \multicolumn{5}{|c|}{$\begin{array}{l}\text { Pre-intervention } \\
\text { level }\end{array}$} & \multicolumn{2}{|c|}{ knowledge } & \multicolumn{7}{|c|}{$\begin{array}{l}\text { Post-intervention knowledge } \\
\text { level }\end{array}$} & \multicolumn{7}{|c|}{$\begin{array}{l}\text { Knowledge level at } 3 \text { months } \\
\text { after intervention. }\end{array}$} \\
\hline & \multicolumn{2}{|c|}{$\begin{array}{l}\text { Poor } \\
(n=203 \\
)\end{array}$} & \multicolumn{2}{|c|}{$\begin{array}{l}\text { Fair } \\
(n=11 \\
3)\end{array}$} & \multicolumn{2}{|c|}{$\begin{array}{l}\text { Good } \\
(n=33 \\
)\end{array}$} & \multirow{2}{*}{$\frac{X^{2}}{[p]}$} & \multicolumn{2}{|c|}{$\begin{array}{l}\text { Poor } \\
(n=26 \\
)\end{array}$} & \multicolumn{2}{|c|}{$\begin{array}{l}\text { Fair } \\
(n=46\end{array}$} & \multicolumn{2}{|c|}{$\begin{array}{l}\text { Good } \\
(n=27 \\
7)\end{array}$} & \multirow{2}{*}{$\begin{array}{l}X^{2} \\
{[p]}\end{array}$} & \multicolumn{2}{|c|}{$\begin{array}{l}\text { Poor } \\
(n=75 \\
)\end{array}$} & \multicolumn{2}{|c|}{$\begin{array}{l}\text { Fair } \\
(n=11 \\
4)\end{array}$} & \multicolumn{2}{|c|}{$\begin{array}{l}\text { Good } \\
(n=16 \\
0)\end{array}$} & \multirow{2}{*}{$\begin{array}{l}X^{2} \\
{[\mathrm{p}]}\end{array}$} \\
\hline & $\mathrm{n}$ & $\%$ & $\mathrm{n}$ & $\%$ & $\mathrm{n}$ & $\%$ & & $\mathrm{~N}$ & $\%$ & $\mathrm{n}$ & $\%$ & $\mathrm{n}$ & $\%$ & & $\mathrm{n}$ & $\%$ & $\mathrm{n}$ & $\%$ & $\mathrm{n}$ & $\%$ & \\
\hline $\begin{array}{l}\text { Total } \\
\text { practice } \\
\text { level }\end{array}$ & & & & & & & & & & & & & & & & & & & & & \\
\hline $\begin{array}{l}\text { Unsatis } \\
\text { factory }\end{array}$ & $\begin{array}{l}2 \\
0 \\
3\end{array}$ & $\begin{array}{l}10 \\
0.0\end{array}$ & $\begin{array}{l}3 \\
3\end{array}$ & $\begin{array}{l}2 \\
9 . \\
2\end{array}$ & $\begin{array}{l}2 \\
1\end{array}$ & $\begin{array}{l}6 \\
3 . \\
6\end{array}$ & $\begin{array}{l}189 . \\
309\end{array}$ & $\begin{array}{l}2 \\
3\end{array}$ & $\begin{array}{l}8 \\
8 . \\
5\end{array}$ & $\begin{array}{l}3 \\
6\end{array}$ & $\begin{array}{l}7 \\
8 . \\
3\end{array}$ & $\begin{array}{l}1 \\
3 \\
4\end{array}$ & $\begin{array}{l}4 \\
8 . \\
4\end{array}$ & $\begin{array}{l}26.7 \\
51\end{array}$ & $\begin{array}{l}7 \\
2\end{array}$ & $\begin{array}{l}9 \\
6 . \\
0\end{array}$ & $\begin{array}{l}8 \\
1\end{array}$ & $\begin{array}{l}7 \\
1 . \\
1\end{array}$ & $\begin{array}{l}9 \\
1\end{array}$ & $\begin{array}{l}5 \\
6 . \\
9\end{array}$ & $\begin{array}{l}37.2 \\
66\end{array}$ \\
\hline $\begin{array}{l}\text { Satisfac } \\
\text { tory }\end{array}$ & 0 & 0.0 & $\begin{array}{l}8 \\
0\end{array}$ & $\begin{array}{l}7 \\
0 . \\
8\end{array}$ & $\begin{array}{l}1 \\
2\end{array}$ & $\begin{array}{l}3 \\
6 . \\
4\end{array}$ & $\begin{array}{l}{[<0 .} \\
001]\end{array}$ & 3 & $\begin{array}{l}1 \\
1 . \\
5\end{array}$ & $\begin{array}{l}1 \\
0\end{array}$ & $\begin{array}{l}2 \\
1 . \\
7\end{array}$ & $\begin{array}{l}1 \\
4 \\
3\end{array}$ & $\begin{array}{l}5 \\
1 . \\
6\end{array}$ & $\begin{array}{l}{[<0 .} \\
001]\end{array}$ & 3 & $\begin{array}{l}4 . \\
0\end{array}$ & $\begin{array}{l}3 \\
3\end{array}$ & $\begin{array}{l}2 \\
8 . \\
9\end{array}$ & $\begin{array}{l}6 \\
9\end{array}$ & $\begin{array}{l}4 \\
3 . \\
1\end{array}$ & $\begin{array}{l}{[<0 .} \\
001]\end{array}$ \\
\hline
\end{tabular}

\section{Discussion:}

According to the socio-demographic characteristics of the studied workers, the current study revealed that three-fifths of them aged between 30 to less than 40 years old, this result was in agreement with Ahmed,\&Shareef, (2019), who conducted 
study about knowledge, practice related to occupational health and safety among chemical company in Eastern India, found that age directly or indirectly influences human behavior towards occupational health and safety, as the age of their study population ranged between 30 to 50 years.

As regards the studied worker's education, the present study result showed that near to two thirds of them had secondary schools or technical diploma, this finding was in agreement with Mousa et al. (2019), who conducted study about assessment of knowledge and self-reported practices of iron mines' workers about pneumoconiosis in Baharia Oasis, found that around two third of the studied population had secondary technical education. This may be explained by the nature of the work witch need employers graduated from secondary technical schools.

Concerning the marital status of the studied workers, four fifths of them were married, this finding was in agreement with Awad\&Aboud, (2019), who conducted study about occupational hazards and preventive measures among waste collection workers, reported that more than three quarters of the studied sample were married.

Regarding family size of the studies workers the most them had moderated family size (3-5 members), the same result was in agreement with Ricciardi et al., (2021), who carried out study about occupational health hazards among El-Araby electronic industry workers at Alex City, found that the majority of the studied workers had moderate family size (3-5 members).

Regarding to total knowledge score of studied worker's among pre, post, after 3 months, the present study showed that 9.5 of studied workers had good of total level of knowledge pre-intervention which increase to 79.4 in post -intervention and became 45.8 3 months after intervention, there were highly statistical significant difference between the worker's chemical fertilizers knowledge and total knowledge $(\mathrm{P}<0.001)$, this finding was in agreement Maliha et al., (2021) who clarified that who reported that $75.4 \%$ of the study participants had good knowledge post program. Also, this study finding was in the same line with Seliman et al., (2018), who found that there was significant improvement in the overall knowledge level before, after and after 3 months the educational program for fertilizer and chemical workers.

Regarding to reported practices domains of the studied worker's related to first aid in case of, burns, bleeding and wound, fractures, electric shock, This result of the present study showed that there were highly statistical significant difference among practice domains $\mathrm{P}<0.001$. The previous result was consistent with Ala'a et al, (2018) who reported that there was highly statistically significant improvement of workers ` first aid practice domains for pre and post after program with $\mathrm{p}$ value $<0.001$.

Regarding to total practice level of studied worker's among pre, post, after 3 months, the present study showed that 26.4 of studied workers had satisfactory total level of practice pre-intervention which increase to 44.7 in post -intervention and became 30.1 after 3 months intervention The total mean score of their practices in first aid $17.2 \pm 6.9$ in pre program to $23.1 \pm$ 3.8 and $20.6 \pm 3.7$ after 3 months, there were highly statistical significant difference of worker's practice level $(\mathrm{P}<0.001)$ The previous result was consistent with Tabash 
et al., (2018) who reported that there was highly statistically significant improvement of workers ` first aid practice domains for pre and post after program with $\mathrm{p}$ value $<0.001$, that generally high level scores of practices. The total mean score of their practices in particular, first aid increased from $15.4 \pm 5.3$ in pre sessions implementation to $21.3 \pm 4.9$ after session. First aid training could help to overcome the motivational problem that workers' direct personal experience of serious negative occupational health and safety consequences. It also seems likely that participants' have stronger belief that they could personally experience an occupational injury or illness. Consequently, first aid training would be a valuable supplement to such training programs and could enhance their preventive effect.

Concerning the relation between the studied workers` total knowledge and total practices; the present study revealed that there was a positive statistically significant relation between the studied workers` total knowledge and total practices pre, post and at 3months after intervention. $(\mathrm{P}<0.001)$, from the researcher point of view, this might be due to attributed to the fact that the knowledge was the baseline of practices and affect positively on their practices. This study finding agreed with El-Ghany\& Mahmoud, (2019), who reported that there was a positive association between total workers' knowledge and total practices level was highly statistical significant $\mathrm{p}$ value equal $(<0.001)$.

\section{Conclusion}

There relation improvement between socio demographic characteristics of workers with their total knowledge level, total practice level at pre, post program and 3 months after program. Also there was a significant relation between total knowledge level \&total practice level of workers at pre and post program and 3 months after program. Also the program succeeded to improve workers practices regarding use of personal protective equipment and first aid one -fifth of them had satisfactory practice preprogram increase to around half post program and one -third after 3 months.

\section{Recommendations:}

- Educational intervention and awareness programs for workers regarding safety measure and first aid of occupational health hazards should be provided in wide score.

- Improvement awareness about training courses for workers regarding safety measure and first aid of occupational health hazards.

- Continuous in-service training programs and refreshing courses should be conducted for workers to update their knowledge and practice about preventing occupational health hazards.

- Workshop regarding the best practices toward safety measure and first aid of occupational health hazards.

\section{References}

Ahmed, A., \&Shareef, H. (2019). Assessment of Occupational Health and Safety Measures' Knowledge and Experienced Types of Hazards among Nursing Staff in Rania Hospital. Erbil Journal of Nursing and Midwifery, 2(2): P 85-92.

Ala'a, S., Sabor, S., \&Aldubai, A. (2018). Knowledge and practice of first aid among parents attending primary health care centers in Madinah City, Saudi Arabia, A cross sectional study. Journal of family medicine and primary care, 7(2):P 380.

Awad, I., \&Aboud, A. (2019). Knowledge, attitude and practice towards antibiotic use 
among the public in Kuwait. PloS one, 10 (2), e0117910.

\section{Egyptian Environmental Affairs Agency}

(EEAA) (2019). Egyptian Pollution Abatment Project (EPAP). Inspection Manual Fertilizers Industry: 1-25. Available at: http:// www. Industry.eeaa.gov.eg/ publications/ fertilizers\%20\%20IM\%202003.pdf

El-Ghany, M., \& Mahmoud, F. (2019). Effect of educational intervention about first aid and ergonomics on improving bakery workers' performance related to occupational hazards at Zagazig City. Egyptian Nursing Journal, 16(1): P 10.

International Labor Organization (ILO), (2017).Comparative analysis of the burden of injury and illness at work in selected countries and regions. Cent. Eur. J. Occup. Environ. Med, 23: P 6-31.

Levy, B. (2019). Occupational and environmental health: recognizing and preventing disease and injury. Lippincott Williams \& Wilkins, 12(5): P25-32.

Maliha, N., Abu Aisheh, I., Tayeh, A., \&Almalki, A. (2021). Safety Barriers Identification, Classification, and Ways to Improve Safety Performance in the Architecture, Engineering, and Construction (AEC) Industry: Review Study. Sustainability, 13(6): P3316.

Mousa, K. M., Fouad, N. A., \& EL-DEIN, S. A. B. (2019). Assessment of Knowledge and Self-Reported Practices of Iron Mines' Workers about Pneumoconiosis in Baharia Oasis, Giza Governorate. Med. J. Cairo Univ, 82(2), 23-29.

Peterson, S. (2018). "About PFA". The National Child Traumatic Stress Network. Retrieved : P11-20.

Ricciardi, V., Mehrabi, Z., Wittman, H., James, D., \& Ramankutty, N. (2021).Higher yields and more biodiversity on smaller farms. Nature Sustainability, P1-7.

Seliman, M., Morsy, Y., Sultan, A., Elshamy, F., \& Ahmed, E. (2018). Impact of a designed head trauma nursing management protocol on critical care nurses' knowledge and practices at emergency hospital Mansoura University. Journal of American science, 10(12):P 13-25.

Tabash, I., Hussein, A., Mahmoud, H., ElBorgy, D., \& Abu-Hamad, A. (2016). Impact of an intervention programme on knowledge, attitude and practice of healthcare staff regarding pharmaceutical waste management, Gaza, Palestine. Public health, 138: P127-137.

Wang, B., Wu, C., Kang, L., Huang, L., \& Pan, W. (2018). What are the new challenges, goals, and tasks of occupational health in China's Thirteenth Five-Year Plan (13th FYP) period?. Journal of occupational health, 2017-0275.

Wilcock, A. (2020). An occupational perspective of health. Slack Incorporated.PMC.5(3), P15.

World Health Organization. (2017): Global plan of action on workers health: 2017. Sixtieth World Health Assembly. WHO 60.26. Agenda item 12: P13.

World Health Organization (2019). Global strategy on occupational health for all: the way to health at work, recommendation of the Second Meeting of the WHO Collaborating Centres in Occupational Health, : P11-14.

World Health Organization (2018): Detection of occupational health hazards. Geneva, Switzerland WHO Back to cited text no. 24.

Yamane, T. (1967): Statistics, An Introductory Analysis, $2^{\text {nd }}$ Ed., New York: Harper and Row. 
برنامـج اجر اعات السلامـه والاسعافات الاوليه بين عمال شركه الالتا للاسمده والصناعات الكيماويه فيما يتعلق بمخاطر الصحه المهنيه

$$
\text { مي نور الدين حمحد - هويدا صادق عبد الحميد - دعاء محمد صبحي السيد }
$$

تدابير السلامة هي استر اتيجيات تهدف إلى القضاء أو تقليل حدوث العوامل الخطرة في بيئة العمل إلى مستويات مقبولة. لذا هدفت هذه الدر اسة الي تقييم إجر اءات السلامة وبرنامج الإسعافات الأولية بين العاملين في شركة دلتا للأسمدة والكيماويات فيما يتعلق بمخاطر الصحة المهنية. حيث تم تنفيذ الدراسة في شركة الدلتا للكيماويات و البذور في مدينة طلخا على و؟ب عاملا. حيث كثفت النتائج كان هناك تحسن كبير في معلومات العمال وممارساتهم حول السلامة والصحة المهنية بعد تنفيذ البرنامج. كما اوصت الدراسه باهميه تنفيذ برامج التدخل التربوي والتو عية للعمال فيما يتعلق بإجر اءات السلامة والإسعافات الأولية لمخاطر الصحة المهنية. 